intractable variety, which had resulted in the tertiary referral of our patients to an incontinence clinic.

Over $23 \%$ of the normal adults (631/2707) had spina bifida occulta; as they had not been subjected to a formal study we do not know whether any of them had neurological defects too minor to warrant clinical referral. In these subjects the bony lesion may not be associated with any nerve deficit, or the absence of associated factors contributing to neurological damage may leave them symptom free.

Despite the significant correlation between the presence of spina bifida occulta and urodynamic abnormalities, no specific correlation was found between the bony defect and any abnormal neurophysiological response. James and Lassman showed in their patients with spina bifida occulta that the neurological lesions were due not to direct interference with nerves in the spina bifida defect but to traction effects from cord tethering or to compression effects on the conus and cauda equina from associated lesions such as lipomas. ${ }^{4}$ Similar lesions in our patients may have been contributory in the development of neurogenic defects. Alternatively our results may indicate the lack of any direct association between the radiological and neurophysiological findings and suggest that both are the result of abnormal development of the tail bud in early gestation but that there is no direct causal link. It is important for future studies to establish whether there are lesions in some of these patients causing pressure or traction effects as these lesions may be amenable to surgery.

1 Cowie TN. Congenital spinal deformities of surgical importance. Acta Radiol 1956;46:38-47

2 Southworth JD, Bersack SR. Anomalies of the lumbosacral vertebrae in five hundred and fifty individuals without symptoms referrable to the low back. A7R 1950:64:624:34.

3 Romanes GJ, ed. Cunningham's textbook of anatomy. Oxford: Oxford University ress, 1981:98.

4 James CCM, Lassman LP. Spina bifida occulta. London: Academic Press, 1981 .

Sutow $\mathrm{W} W$, Pryde $\mathrm{AW}$. Incidence of spina bifida occulta in relation to age. AMA Journal of Diseases of Children 1950;91:211-7.

6 Lemire RJ, Beckwith JB. Pathogenesis of congenital tumors and malformations in the sacrococcygeal region. Teratology 1982;25:201-13.

Galloway NTM, Tainsh J. Minor defects in the sacrum and neurogenic bladder dysfunction. Br f Urol 1985;57:154-5.

8 Fidas A, Elton RA, McInnes A, Chisholm GD. Neurophysiological measurement of the voiding reflex arcs in patients with functional disorders of the lower urinary tract. $\mathrm{Br}$ f Urol 1987;60:205-11.

9 Fidas A, Galloway NTM, McInnes A, Chisholm GD. Neurophysiological measurements in primary adult enuretics. Br f Urol 1985;57:635-40.

10 Fidas A, MacDonald HL, Elton RA, Wild SR, Chisholm GD, Scott $R$ Prevalence and patterns of spina bifida occulta in 2707 normal adults. Clin Radiol 1987;38:537-42.

11 Scott $\mathrm{R}$, Freeland $\mathrm{R}$, Mowat $\mathrm{H}$, et al. The prevalence of calcified upper urinary tract stone disease in a random population-Cumbernauld health survey. Br f Urol 1977;49:589-95.

(Accepted 29 November 1988)

\title{
Optimum duration of antithyroid drug treatment determined by assay of thyroid stimulating antibody in patients with Graves' disease
}

\author{
Gilles Edan, Catherine Massart, Bernard Hody, Jean Yves Poirier, Maurice Lé Reun,
} Jean Pierre Hespel, Gérard Leclech, Marcel Simon

\section{Abstract}

Objective-To determine the optimal duration of antithyroid drug treatment by monitoring serum thyroid stimulating antibody values in patients with Graves' disease.

Design-Prospective longitudinal trial of patients with Graves' disease followed up for $\mathbf{2 4}$ months after withdrawal of treatment.

Setting-Tertiary referral centre.

Patients - A total of 64 consecutive patients with

Clinique Médicale B,

Hôpital Sud, BP 22129,

35056 Rennes, France

Gilles Edan, MD, consultant endocrinologist

Jean Yves Poirier, MD, endocrinologist

Maurice Lé Reun, MD, endocrinologist

Jean Pierre Hespel, MD, professor, consultant endocrinologist

Marcel Simon, MD, professor, department of endocrinology

Services d'Hormonologie et d'Oto-Rhino-

Laryngologie,

Pontchaillou, Rennes,

France

Catherine Massart, PHD, biochemist

Bernard Hody, biochemist Gérard Leclech, MD,

professor of surgery

Correspondence to: $\mathrm{Dr}$ Edan.

$\operatorname{BrMed}$ f 1989;298:359-61 untreated Graves' disease, eight of whom were subsequently excluded. Fifty six patients completed the study.

Interventions - All patients were treated initially with carbimazole $40 \mathrm{mg}$, then with decreasing doses that maintained a euthyroid state. Treatment was scheduled to continue for 18 months but was withdrawn earlier if serum thyroid stimulating antibody became undetectable.

End point-Serum values of thyroid stimulating antibody (assayed by stimulation of human thyroid cells in vitro) and thyroid hormones and thyroid state every three months during treatment and afterwards every six months for $\mathbf{2 4}$ months.

Measurements and main results-In 44 patients serum thyroid stimulating antibody became undetectable during treatment and treatment was withdrawn (median duration of treatment nine months, range 3-18 months). In 12 patients the antibody could be detected during 18 months of treatment. Among the first group of 44 patients initial values of the antibody before treatment were significantly lower than in the second group of 12 patients (median 225\% (range 138-1236\%) v 570\% (250-1480\%), $\mathbf{p}<0.001)$; the incidence of relapse was also lower $(41 \% v 92 \%, \mathrm{p}<0.001)$; and among those who did relapse the disease free interval after treatment was longer (median 12 months $v 1$ month, $\mathbf{p}<\mathbf{0 . 0 0 1}$ ). Moreover, the initial median serum values of thyroid stimulating antibodies were not related to the occurrence of relapse or remission as these did not differ between patients who did and did not have a relapse (median $267 \%$ (range $139-1480 \%$ ) $v 220 \%$ (range 138-1236\%).

Conclusion-Monitoring of serum thyroid stimulating antibody was a good guide to the duration of treatment as it allowed the treatment period to be considerably shortened in a large group of patients with no loss of efficiency.

\section{Introduction}

Patients with Graves' disease may be treated with ablative or non-ablative treatment. Thyroidectomy is rapid and radioactive iodine treatment simple for the patient; both are effective in the long term but carry an obvious risk of hypothyroidism..$^{1-3}$ Non-ablative treatment with antithyroid drugs is less efficient but preferred by many as the best choice for new patients because it is well tolerated and does not carry the risk of secondary hypothyroidism..$^{45}$ Both short term ${ }^{67}$ and long term ${ }^{84}$ treatments have been proposed. We aimed at determining whether drug treatment could be stopped more appropriately when serum thyroid stimulating antibody became undetectable.

\section{Patients and methods}

Patients-Sixty four untreated patients with Graves' disease diagnosed by clinical signs of hyperthyroidism accompanied by increased thyroid hormone concentrations (free triiodothyronine $>8.9 \mathrm{pmol} / \mathrm{l}$; free thyroxine $>23.4 \mathrm{pmol} / \mathrm{l}$ ) and homogeneous thyroid scans were entered consecutively into the study from July 1983 to June 1985. Eight patients were subsequently excluded 
for the following reasons: serum thyroid stimulating antibody was absent before treatment (three), patients chose surgery before three months of drug treatment had been completed (two), patients left follow up (three). A total of 56 patients remained in the study, consisting of 40 women and 16 men, median age 41 , range 18-67.

Treatment and follow up-All patients were treated with carbimazole, initially at a high dose $(40 \mathrm{mg}$ a day) followed by decreasing doses that maintained a euthyroid state without hormone replacement. During the treatment protocol patients were seen every three months. After withdrawal of the drug they were recalled every six months for 24 months for physical examinations and assays of free triiodothyronine, thyroxine, thyroid stimulating hormone, and thyroid stimulating antibody concentrations. Patients were also seen in cases of a relapse. Previously we had treated our patients routinely for 18 months, but in this series the antithyroid drug was withdrawn earlier if thyroid stimulating antibodies became undetectable.

Laboratory tests-Free triiodothyronine and thyroxine concentrations were measured with a radioimmunoassay kit (Amersham International, Amersham, Bucks), and thyroid stimulating hormone was assayed with a kit (Hoechst AG, Frankfurt). Thyroid stimulating antibody was assayed according to the method of Madec et al, ${ }^{10}$ modified by us, ${ }^{11}$ which is more sensitive than radioreceptor techniques. ${ }^{111}$ Briefly, human thyroid cells obtained from patients who were free of thyroid disease were cultured. The cells were dispersed enzymatically with Dispase II (5 g/l), a neutral Bacillus polymyxa protease (EC 3.4.24.4; Boehringer-Mannheim, FRG). Cellular reactivity (production of cyclic adenosine monophosphate) was assessed by stimulation with bovine thyrotrophin (Sigma). To measure the total free cyclic adenosine monophosphate produced during 48 hours' incubation a commercially available protein binding assay (Amersham) was used. All measurements were made with at least two separate assays, each comprising three determinations. Thyroid stimulating antibody activity was expressed as percentage stimulation of thyroid cells (determined by measuring production of cyclic adenosine monophosphate) during 48 hour culture with patients' serum compared with the stimulation resulting with pooled equal volumes of 43 control serum samples. With the control sera the basal values of thyroid stimulating antibody ranged from $78 \%$ to $122 \%(100(22) \%$, mean ( 2 SD)); values $\geqslant 122 \%$ were thus designated as positive and values $\leqslant 121 \%$ as negative.

Statistical analysis-Data were analysed using Wilcoxon's distribution free test and Spearman's test for rank correlation and the $\chi^{2}$ test for proportions.

TABLE I-Comparison of patients in study

\begin{tabular}{|c|c|c|c|}
\hline & $\begin{array}{l}\text { Patients without detectable } \\
\text { thyroid stimulating antibody } \\
\text { during trial }(\mathrm{n}=\mathbf{4 4})\end{array}$ & $\begin{array}{l}\text { Patients with detectable } \\
\text { thyroid stimulating antibody } \\
\text { during trial }(\mathrm{n}=12)\end{array}$ & Comparison \\
\hline $\begin{array}{l}\text { Percentage of patients (confidence } \\
\text { interval) }\end{array}$ & 79 (68 to 89$)$ & $21(11$ to 32$)$ & \\
\hline Sex & $32 \mathrm{~F}, 12 \mathrm{M}$ & $8 \mathrm{~F}, 4 \mathrm{M}$ & $\mathrm{NS}^{\star}$ \\
\hline Median (range) age (years) & $43(18-67)$ & $37(21-62)$ & NSt \\
\hline $\begin{array}{l}\text { Median (range) initial free } \\
\text { triiodothyronine }(\mathrm{pmol} / \mathrm{l})\end{array}$ & $24 \cdot 1(9 \cdot 2->38)$ & $25(10->38)$ & NSt \\
\hline $\begin{array}{l}\text { Median (range) initial serum } \\
\text { thyroid stimulating antibody }(\%) \ddagger\end{array}$ & $225(138-1236)$ & $570(250-1480)$ & $p<0.001 \dagger$ \\
\hline $\begin{array}{l}\text { Median (range) duration of treatment } \\
\text { (months) } \\
\text { No of patients relapsing }\end{array}$ & $\begin{array}{c}9(3-18) \\
18\end{array}$ & $\begin{array}{l}18 \\
11\end{array}$ & \\
\hline $\begin{array}{l}\text { Percentage of patients (confidence } \\
\text { interval) }\end{array}$ & $41(25$ to 57$)$ & $92(55$ to 100$)$ & $\mathrm{p}<0.00 \mathrm{l}^{\star}$ \\
\hline $\begin{array}{l}\text { Median (range) interval free of disease } \\
\text { in patients in relapse after } \\
\text { treatment (months) }\end{array}$ & $12(1-24)$ & $1(1-6)$ & $\mathrm{p}<0.001 \dagger$ \\
\hline
\end{tabular}

\section{Results}

Of the 56 patients, $44(79 \%)$ without detectable thyroid stimulating antibody before the end of the treatment period were assigned to one group and the 12 $(21 \%)$ in whom the assay remained positive at the end of the 18 months' treatment were assigned to another group. Patients in both groups were not significantly different in age, sex, or initial thyroid hormone concentrations (table I). In the first group treatment lasted a median of 9 (range 3-18) months. In all of these the median duration of treatment was nine months shorter than the standard 18 months.

The relapse rate in patients with detectable thyroid stimulating antibody was significantly increased $(92 \%$ $\left.v 41 \% ; \chi^{2}=9 \cdot 72, \mathrm{df}=1, \mathrm{p}<0.001\right)$. In patients without detectable antibody the relapse rate was independent of duration of treatment $\left(\chi^{2}=2 \cdot 25, \mathrm{df}=4\right)$ (table II).

TABLE II -Relapse or remission during follow up in patients treated for Graves' disease whose serum thyroid stimulating antibody concentration became undetectable or remained detectable during treatment. (Figures are numbers of patients)

\begin{tabular}{llrr}
\hline $\begin{array}{l}\text { Duration of } \\
\text { treatment } \\
\text { (months) }\end{array}$ & Remission & Relapse & Total \\
\hline & Patients without detectable antibody & \\
3 & 4 & 4 & 8 \\
6 & 6 & 7 & 13 \\
9 & 7 & 3 & 10 \\
12 & 5 & 2 & 7 \\
15 & 2 & 2 & 4 \\
18 & 2 & 0 & 2 \\
& Patients with detectable antibody & \\
18 & 1 & 11 & 12
\end{tabular}

TABLE III - Relapse rate of hyperthyroidism as function of presence or absence of detectable thyroid stimulating antibody at drug withdrawal. (Numbers of patients in parentheses)

\begin{tabular}{|c|c|c|}
\hline Reference & $\begin{array}{l}\text { Thyroid stimulating } \\
\text { antibody detectable }\end{array}$ & $\begin{array}{l}\text { Thyroid stimulating } \\
\text { antibody not detectable }\end{array}$ \\
\hline Zakarija et al's & $100(12 / 12)$ & $18(3 / 16)$ \\
\hline Bech and Madsen & $90(9 / 10)$ & $28(5 / 19)$ \\
\hline Romaldini et al" & $53(15 / 28)$ & $28(8 / 28)$ \\
\hline Rapoport et al $l^{\circ}$ & $71(5 / 7)$ & $0(0 / 12)$ \\
\hline Madec et al $l^{\prime \prime \prime}$ & $68(21 / 31)$ & $33(8 / 24)$ \\
\hline Van Ouwerkerk et al & $66(8 / 12)$ & $35(6 / 17)$ \\
\hline Total & $70(70 / 100)$ & $25(30 / 116)$ \\
\hline
\end{tabular}

In patients with a relapse the interval free of disease after finishing treatment was longer in the group without detectable antibody (median 12 months (range 1-24 months) $v 1$ (1-6) months; Wilcoxon's test, $\mathrm{z}=-4 \cdot 158, \mathrm{p}<0 \cdot 001)$. In the patients without detectable antibody with a relapse this interval was not significantly correlated with duration of treatment (Spearman's test, $\mathrm{r}_{\mathrm{s}}=0 \cdot 196, \mathrm{df}=16$ ).

The initial median thyroid stimulating antibody values before treatment were significantly lower in patients without detectable antibody (225\% (138$1236 \%) v 570 \%$ (250-1480\%); Wilcoxon's test, $\mathrm{z}=-3.96, \mathrm{p}<0.001)$. The initial median values of thyroid stimulating antibody did not, however, predict a relapse or remission as the initial values in the 29 patients with a relapse $(267 \%(139-1480 \%))$ and the 27 who remained in remission $(220 \%(138-1236 \%))$ were not significantly different (Wilcoxon's test, $z=-0.943$ ). In patients with a relapse in the group without detectable antibody during treatment the initial thyroid stimulating antibody values also did not correlate significantly with the interval free of disease after drug withdrawal (Spearman's test, $\mathrm{r}_{\mathrm{s}}=0 \cdot 07, \mathrm{df}=$ 16).

All patients without detectable thyroid stimulating antibody who remained in remission throughout the 24 months of follow up had negative results on assay 
for the antibody during this time. Fourteen of the 18 patients with a relapse whose antibodies became undetectable during treatment had detectable antibody at relapse (median $220 \%$, range $95-565 \%$ for the 18 patients). In the patients with detectable antibody during treatment the values at relapse were not significantly different from those at the end of the 18 months of treatment $(187 \%(146-644 \%) v 195 \%$ $(134-320 \%)$; Spearman's test, $\left.r_{s}=0 \cdot 39, d f=9\right)$. One patient remained in remission despite having positive values for the antibody for 12 months.

\section{Discussion}

This is the first prospective longitudinal study designed to evaluate the value of thyroid stimulating antibody assay in determining the duration of drug treatment in Graves' disease. Thyroid stimulating antibodies are highly specific for Graves' disease and their value usually decreases during treatment. ${ }^{12}$ Our assay is very sensitive, giving positive results in $95 \%$ of untreated cases. Our findings support the hypothesis that repeated assay of thyroid stimulating antibody could give valuable information concerning the best time to withdraw antithyroid drugs: the rate of relapse in patients whose drug treatment was withdrawn when the assay gave negative results was significantly lower $(41 \%)$ than that in patients whose treatment was withdrawn after a fixed course of 18 months despite positive results for thyroid stimulating antibody $(91 \%)$. The rate of relapse and the disease free interval were not correlated with the time it took for the antibody to become negative. With a negative test result for thyroid stimulating antibody as the signal to stop the antithyroid drug treatment the duration of treatment was significantly reduced (median reduction nine months for 56 patients in our series). A low initial value for thyroid stimulating antibody before treatment predicted early remission.

Randomised prospective studies have shown a correlation between remission rates and duration of treatment; in patients treated for six months the rates were $31 \%{ }^{13}$ and $41 \cdot 7 \%,{ }^{14}$ whereas treatment for 18 months to two years increased the rates to $79 \%{ }^{13}$ and $61 \cdot 8 \%{ }^{1+}$ These results are consistent with our findings as the proportion of patients without detectable thyroid stimulating antibody increased from $37 \%$ at six months to $79 \%$ at 18 months. Remission rates and doses of antithyroid drugs for a fixed period are directly correlated. ${ }^{15}$ The remission rates were higher in patients who received high doses of antithyroid drugs than in patients who received decreasing doses $(75.4 \% v$ $41.6 \%$, respectively). The percentage of patients without detectable thyroid stimulating antibody at the end of the treatment was higher in the higher dose group $(71 \% v 29 \%)$, suggesting an immunosuppressive action. In our opinion this finding suggests that high doses could reduce the duration of necessary treatment.

Our findings confirm early reports that showed the lack of correlation between the values of thyroid stimulating antibody before the onset of treatment and risk of relapse. ${ }^{1617}$ Assay of the antibody at diagnosis thus does not give any clear indication for choosing the treatment regimen. Reports of an assay similar to ours (table III), an assay for thyroid stimulating hormone receptor antibodies, or other techniques, ${ }^{21-2 x}$ have consistently shown an increased risk of relapse in patients who are positive for thyroid stimulating antibody at the end of treatment. Nevertheless, opinions differ about the usefulness of the assay at the end of treatment. The possibility of long term remission despite the presence of thyroid stimulating antibody, relapse in patients without detectable antibody and the requirement of follow up after drug withdrawal, whatever the antibody value have led several authors to place little predictive value on this variable. ${ }^{161719}$ In fact, the presence of thyroid stimulating antibody is only a marker of immunological activity responsible for hyperthyroidism. We think, therefore, that thyroid stimulating antibody values are a useful guide to the duration of treatment, as their monitoring allowed the treatment period to be considerably shortened in a large group of patients with no loss of efficiency.

The technical help of M P Lefoie and M C Roumieux is gratefully acknowledged.

Professor Marcel Simon died in an accident on 11 August 1988.

I Michie W, Pegg CAS, Bewsher PD. Prediction of hypothyroidism after partial thyroidectomy for thyrotoxicosis. Br.Med f 1972;i:13-7.

2 Toft AD, Irvine WJ, Sinclair I, McIntosh D, Seth J, Cameron EHD. Thyroid function after surgical treatment of thyrotoxicosis. A report of 100 cases treated with propranolol before operation. N Engl f Med 1978;298:643-7.

3 Sridama V, McCormick M, Kaplan EL, Fauchet R, De Groot LJ. Long term Sridama V, McCormick M, Kaplan EL, Fauchet R, De Groot LJ. Long term
follow up study of compensated low dose'"I therapy for Graves' disease. follow up study of compensated
N Engl F Med 1984;311:426-32.

4 Glinoer D, Hesch D, Lagasse R, Laurberg P. The management of hyperthyroidism due to Graves disease in Europe in 1986. Results of an international survey. Acta Endocrinol 1987;115(suppl 285):6-23.

5 Cooper DS. Antithyroid drugs. N Engl F Med 1984;311:1353-62.

6 Greer MA, Kammer H, Bouma DJ. Short term antithyroid drug therapy for the thyrotoxicosis of Graves' disease. N Engl f.Med 1977;297:173-6.

Bing RF, Rosenthal FI). Early remission in thyrotoxicosis produced by short courses of treatment. Acta Endocrinol 1982;100:221-3.

8 Burr WA, Fitzgerald MG, Hoppenberg R. Relapse after short-term antithyroid therapy of Graves' disease. $N$ Engl f Med 1979;300:200.

9 Slingerland DW, Burrows BA. Long-term antithyroid treatment in hyperthyroidism. FAMA 1979;242:2408-10.

10 Madec AM, Laurent MC, Rostagnat-Stefanutti A, Allannic H, Orgiazzi J, Mornex R. Thyroid stimulating antibody (TSAb) assay in whole serum Mornex $R$. Thyrold stimulating antibody (TSAb) assay in whole
using cultures of human thyroid cells. Presse Med 1983;12:1849-53.

11 Massart C, Hody B, Mouchel L, Edan G, Nicol M. Assays for thyrotropinreceptor binding and thyroid stimulating antibodies in sera from patients with Graves' disease. Clin Chem 1986;32:1332-5.

12 Sugenoya A, Kidd A, Row VV, Volpe R. Correlation between thyrotropindisplacing activity and human thyroid-stimulating activity by immunoglobulins from patients with Graves' disease and other thy roid disorders. fClin Eindocrinol Metab 1979;48:398-402.

13 Tamai H, Nakagawa 'T, Fukino O, et al. Thionamide therapy in Graves' disease: relation of relapse rate to duration of therapy. Ann Intern Med 1980;92:488-90.

14 Allannic H, Orgiazii J, Lorcy Y, Le Guerrier AM, Fauchet R, Genetet B. Relapse rate in patients with Graves' disease treated with anti-thyroid drugs: a prospective randomized study of treatment duration. Ann Endocrinol (I'aris) 1986;47:30.

15 Romaldini JH, Bromberg N, Werner RS, et al. Comparison of effects of high and low dosage regimens of antithyroid drugs in the management of Graves' and low dosage regimens of antithyroid drugs in the manage
hyperthyroidism. F Clin Endocrinol Metab 1983;57:563-70.

16 Madec AM, Laurent MC, Lorcy Y, et al. Thyroid stimulating antibodies: an Madec $\mathrm{AM}$, Laurent $\mathrm{MC}$, Lorcy Y, et al. Thyroid stimulating antibodies: an
aid to the strategy of treatment of Graves' disease? Clin Endocrinol (Oxf) aid to the strategy
$1984: 21: 247-55$

17 Van Ouwerkerk BM, Krenning EP, Docter R, $c t$ al. Cellular and humoral immunity in patients with hyperthyroid Graves' disease before, during and after antithyroid drug treatment. Clin Endocrinol (Oxf) 1987;26:385-94

18 Zakarija M, McKenzic JM, Banovac K. Clinical significance of assay of thyroid-stimulating antibody in Graves' disease. Ann Intern Med 1980;93 28-32.

19 Bech K, Madsen SN. Influence of treatment with radioiodine and propylthioracil on thyroid stimulating immunoglobulins in Graves' disease. Clin Endocrinol (Oxf) 1980;13:417-24.

20 Rapoport B, Greenspan FS, Filetti S, Pepitone M. Clinical experience with a human thyroid cell bioassay for thyroid-stimulating-immunoglobulin. f Clin Endocrinol Metab 1984;58:332-8.

21 Davies TF, Yeo PPB, Evered DC, Clark F, Rees Smith B, Hall R. Value of thyroid-stimulating antibody determinations in predicting short-term of thyroid-stimulating antibody determinations in predic
thyrotoxic relapse in Graves' disease. Lancet 1977; i: $1181-2$.

22 Teng CS, Yeung RTT. Changes in thyroid-stimulating antibody activity in Graves' disease treated with antithyroid drug and its relationship to relapse: a prospective study. I Clin Endocrinol Metab 1980;50:144-7.

23 Takata I, Suzuki Y, Saida K, Sato T. Human thyroid stimulating activity and clinical state in antithyroid treatment of juvenile Graves' disease. Actu Endocrinol 1980;94:46-52

24 McGregor AM, Rees Smith B, Hall R, Petersen MM, Miller M, Dewar PJ. Prediction of relapse in hyperthyroid Graves' disease. Lancet 1980;i:1101-3.

25 Bliddal H, Kirkegaard C, Siersbaek-Nielsen K, Friis T. Prognosis value of thyrotropin binding inhibiting immunoglobulins in long term antithyroid treatment "I $^{\prime \prime}$ therapy given in combination with carbimazole and in treatment 1 therapy given in combination with carbimath

26 Hardisty CA, Hanford L, Munro DS. The prediction of relapse after drug treatment of Graves' disease by assay of long acting thyroid stimulatortreatment of Grases disease by assay of long acting thyr
protector (LATS-P). Clin Endocrinol (Oxf) 1981;14:509-17.

27 Gossage AAR, Grawlex JCW. Copping S, Hinge D, Hinsworth RL. Thyroid function and immunological activity during and after medical treatment of function and immunological activity during and after
Graves' disease. Clin Endocrinol $(O x f)$ 1983;19:87-96.

28 Schleusener H, Schwander J, Holl G, $e t$ al. Do HLA-DR typing and measurement of TSH-receptor antibodies help in the prediction of the clinical course of Graves' thyrotoxicosis after antithyroid drug treatment? Acta Endocrinol 1987;281:318-24.

Accepted 28 November 1988 